\title{
Same Urban Legends, Different Bad Hombres: The Risk of Narratives across Borders about Deviant Others
}

Gonzalo Soltero

National Autonomous University of Mexico

\section{Introduction}

When Donald Trump announced his presidential bid in June 20 I 5 , he mentioned that Mexico usually sent across the border: "people that have lots of problems, and they're bringing those problems with us. They're bringing drugs. They're bringing crime. They're rapists" (Washington Post, 20I5). Since the third presidential debate he mentioned that there were "some bad hombres here", that were going to be sent out when he took office. During his first telephone conversation with the Mexican president, there were claims that Trump offered (or threatened) to send troops to Mexico to take care of those bad hombres (Agren, 20I7). All along, he repeatedly promised to build a wall along the Mexican border in order to keep such evil men out. Walls, however, have proved completely useless to fend off narratives that allow human groups to characterize others. This chapter is based on the transit of two urban legends regarding crime that became very prolific in Mexico and the United States, which have been called "Lights Out!" and "Burundanga".

Allport and Postman declared rumor to be: "a specific (or topical) proposition for belief, passed along from person to person, usually by word of mouth, without secure standards of evidence being present" (Allport and Postman I947, ix). Urban

How to cite this book chapter:

Soltero, G. 202 I. Same Urban Legends, Different Bad Hombres: The Risk of Narratives across Borders about Deviant Others. In: Jonsson, H., Berg, L., Edfeldt, C. and Jansson, B. G. (eds.) Narratives Crossing Borders: The Dynamics of Cultural Interaction. Pp. 375-403. Stockholm: Stockholm University Press. DOI: https://doi.org/IO.I6993/bbj.q. License: CC-BY 4.0 
(or contemporary) legend is a closely related term that usually refers to a more elaborate narrative, surprising and frequently shocking. These narratives pretend to be news about the immediate environment of senders and recipients, express an urgent social problem that needs attention and attempt control over ambiguous situations (Ellis I990, 2-3). Brunvand declares that these apocryphal stories told as true concern alleged recent events, which usually happened to a "friend of a friend" (I98I, p. xi; I996, p. 730). Such social closeness is useful for understanding their process of transmission, by which they construct verisimilitude: when the events portrayed in these tales happen to 'a friend of a friend', or somebody equally close, they establish an arm's length reliability upon the source of the story that usually belongs to the same group.

Fine and Ellis assert that the limits between these terms are so porous that: "it is impossible to maintain a clear distinction between rumor and legend" (p. 5), therefore, they will be used as partial synonyms. These short and fictive stories that pretend to be true have been examined by a number of perspectives and disciplines, such as folklore studies (e. g. Brunvand I98 I, I995, 2000, 2001. Dégh and Vázsonyi, I983. Dundes, I980, I99I. Ellis I983, 200I), psychology (e. g. Knapp, I944. Allport and Postman, I947)) and sociology (e.g. Best, I999. Donovan, 2004. Fine, I992. Morin, I970).

Rumors and urban legends can be very telling cultural phenomena when analyzing the social processes that give them existence and the meaning they convey. Their content, context and the way they spread can help to assess how the members of a society perceive reality and what they think about other groups. Furthermore, these narratives inform world visions which can alter reality: rumors influence how people from all levels of society think and react, individually and collectively. Fine and Ellis conclude that: "As the rumor process moves toward forming agendas of actions intended to protect a culture against a potential threat, it contributes to political decisions that, for better or worse, can lead to long-lasting social consequences" (p. 204). Donald Trump's claims and proposals for policy above present the same prejudices contained in the transmission of the urban 
legends that will be analyzed in this chapter. The following dictum by Clifford Geertz is a very adequate premise for this study: culture is the ensemble of stories we tell ourselves about ourselves (2000). Urban legends are a very particular strand of stories we tell ourselves about ourselves - and about others. Some of these narratives, especially those legends about ongoing crime, usually contribute to the collective identity of a group by singling out others in opposition to those sharing the tale. Communities may share urban legends to strengthen alliances in difficult periods and to channel social stress, attributing causation to a difficult environment by supplying a fake responsible. In this sense, they are stories we tell ourselves about Them.

Brunvand proposed 'a classification of urban legends which organizes them on the basis of subject matter and content; one of the ten major headings was "Crime" (Brunvand, 200I, pp. 73-76). Crime legend serves as a useful differentiation from the other subtypes of urban legends. This was also the term adopted by Donovan for looking at three urban legends discussed in internet newsgroups between 1995 and 1999 (2004, 3). The urban legends studied here carry a clear implication of risk for those who share them. They are not amusing stories that happened sometime in the past, but a warning about an actual ongoing threat, about the present and the immediate future. Even if these legends recount a horrible story that happened to a friend of a friend, it is not an isolated event: the criminals in the story are out there, on the streets. These narratives can cause considerable distress among those who share them, which largely accounts for their transmission, as recipients pass along the messages mainly to prevent friends and family from the threat the legend warns about. They show a remarkable ability to filter through different communities and all socioeconomic levels; in their oral, written or digital retelling regional details (such as names of streets or shops) are incorporated to become locally verisimilar and resist refutation attempts.

Shibutani argues that: "If rumor is a collective transaction, a satisfactory explanation of it would also require generalizations about things that men do together in units" ( I966, I64). Groups are such units and will be understood as the different segments or 
sums of individuals that constitute society, which usually identify around a collective self (Us) that is formed by characteristics such as ethnic background, social class, interests, education or type of work, but also in opposition to other groups (Them). These type of narratives play an important role in both binding and dividing human groups. Rumors play a functional role in the group that circulates them, therefore every rumor seems to have its own public, something Allport and Postman called 'a community of interest' (p. I 80). One of the functions that they usually carry out is expressing dissent about innovations, modern society, its complexities and possible risks to the established social order (Fine, I992).

Dunbar suggests that language evolved to allow our species to gossip, in order to tighten social bonds (I993, p. 79). Rumors could have followed as early by-products from that dawn of human communication. Folklore provides evidence of how such narrative differentiation of $U s$ from Them has been going on for centuries, even millennia, as in the case of "The Mutilated Boy". This urban legend circulates nowadays warning about the initiation ritual of a youth gang where its members, who generally belong to an ethnic or sexual minority, mutilate the genitals of an abducted boy in the fitting rooms of a shopping mall. Alan Dundes first showed that it branched from "The Blood Libel", an anti-Semitic legend that circulated in Europe since the twelfth century (I99I, p. vii). However, Bill Ellis has pointed out that it goes back even beyond that: anti-Christian versions of this legend "can be found as far back as 63 B. C., and it is probably at least a century older than that. It circulated actively in Rome and other major centers of the Roman Empire for more than three centuries" (2003, p. 50). The members of the gang change their characteristics along the specific time and context where the legend is told, but throughout its retellings and adaptations they always belong to an out-group (Christians, Jews, gays or African Americans).

The Second World War was the cradle of the academic study of rumor. The first authors to publish about the topic, Knapp, Allport and Postman, were psychologists who worked in clinics established in the United States in an attempt to stop the spreading 
of rumors and war propaganda. Knapp appointed three main characteristics of rumor: it is transmitted by word of mouth; it provides information about a particular person, event or condition; and channels the emotional needs of a community (I944, pp. 22-23). Knapp provided a classification based upon the emotions that the legends gratify: pipe-dreams attend to wishes, bogies to fears and anxieties, and wedge-drivers to aggression or hostilities ( 1944, p. 22). From the 1,089 rumors received by the Massachusetts Committee on Public Safety during September I942, over 60 per cent were wedge-drivers, reflecting hate and hostility to other social groups within the same society who were blamed for the predominant uncertainty (Knapp, I944, p. 24).

There is an overall agreement in the literature of what functions these narratives serve: they provide a fictional sensemaking that helps explain an intricate world and alleviates the anxiety felt in current social environments, tightening the social bonds of the immediate group, with which the stories are shared (Knapp, I944, p. 33. Allport and Postman, I947, p. 5. Shibutani, I966, pp. 62, I63-164. Fine and Ellis, pp. 20, 209). The factual information of rumors is almost always incorrect, but it can still be eloquent about the state of mind of whoever passes them on. They reflect the hopes, fears and anxieties of our time and can thus also provide an insight into the structure of the community (Knapp I944, pp. 26, 27. Brunvand,I98 I, p. 2).

In anxiety producing circumstances people seek a cause for their frustration. In such situations "any definition of the source and nature of danger is preferable to none" (Knapp I944, p. 32). While trying to find the source, a plausible nearby target is sought to fix the blame on in order to explain the situation. Rumors succeed because they cast underlying emotional tensions into a target, frequently embodied by the other. The above is characteristic not only of wars. Urban legends address the mistrust that social communities have about those outside their bounds. Hence, multicultural societies are fertile terrain for this type of folkloric creations, as the identities of sub-groups rival among them (Heath 2007, 82. Fine and Ellis p. 20I). Many urban legends feature a clear other that threatens a certain group. Fine and Turner have explored this by looking at the folklore of 
black and white communities addressing each other in the United States (200I). Likewise, Neubauer mentions that during the First World War, German and French troops told very similar stories, adapting characters and other elements to each side (I999, p. 99).

The idea of Them condenses uncertainty into a particular threat and turns anxiety into a concrete fear. By being aware and making others aware of a specific them, these narratives give the illusion of addressing the situation. Trying to understand what caused the predominance of wedge driving rumors during war, Knapp indicated that: "[w]ith a ready scapegoat to look down upon, one never feels quite so inferior, never quite so guilty for one's own misdeeds" ( 1944, p. 33). Paradoxically the price of certitude may be falsity, sentencing as guilty a group or individuals that are usually innocent. "People that accept a rumor reject all uncertainty and make an accusation. The public enemy is unmasked, which is already a relief" (Delumeau, I978, p. 232 -my translation, as the following ones from sources not in English).

This can be exemplified by Bourke's analysis of the rumors caused by the Bethnal Green panic during the Second World War in Britain, where 173 persons were crushed to death by a large group of people rushing to a bomb shelter.

While the official inquiry emphasised structural and procedural flaws, ordinary British citizens were more anxious to identify the "real" culprits. Scapegoating was one of the main responses to the Bethnal Green panic. [...] Foreigners, Jews, criminals and irresponsible young people became the symbolic scapegoats for all that went wrong at the Bethnal Green shelter. Of these four "enemies within", foreigners were regarded as being the most blameworthy (2005, pp. 236-237).

The suspicions about foreigners regarding this accident were also extended to foreign imports, e.g. a faulty substance used to repair shoes that made some people lose their step and thus began the trampling (Bourke, 2005, p. 237). This is how ongoing crime legends condense uncertainty into a specific risk and give a solution to avoid it. The strain caused by social conditions is thus catalyzed into a perceived threat to the community (Best and Horiuchi, I985, p. 496), that makes it possible to act against 
it and feel the support of others instead of experiencing frustration alone.

However, the positive aspect of scapegoating works for Us. The negative one, as Morin observes, is for Them, "[o]nce the responsibility has been pinned down on certain individuals, all the rest are thereby exonerated" (I97I, p. I35). This is where scapegoating brings forth catharsis: by charging the accused with all sort of crimes and vices, the accuser feels purified (Delumeau, I978, p. 232). Such projection of guilt is part of the scapegoating process that allows conveying negative feelings towards already marginalized groups, by blaming them for the perceived decline of society and the uncertainty in the environment.

The absence of a concrete other as an enemy can cause confusion and anxiety. Consider the following quote from George W. Bush, former president of the United States: "When I was coming up, it was a dangerous world, and you knew exactly who they were. It was us versus them, and it was clear who them was. Today we are not so sure who they are, but we know they're there" (in Weisberg, 2000). Here Bush contrasts the Cold War, where communists were a clear enemy of capitalism, with the current period that is far from being set in such binary terms. This explains why sometimes to face uncertainty an enemy is sought or even created, e.g. the Axis of Evil that Bush adopted while president as his international doctrine for action.

\section{The Legends: "Lights Out!" and "Burundanga"}

I will briefly describe the urban legends and their transit, as I have studied them at length elsewhere (e.g. Soltero, 20I6a. Soltero, 20I6b). "Lights Out!" has been one of the most commented urban legends on by scholars (e. g. Best and Horiuchi, I985. Brunvand, I995, 2000, 200I. Fine and Turner, 200I. Ellis, 2003. Donovan, 2004). It spread intensely in the United States in 1993 and in Mexico twelve years later. The text was almost identical in both cases:

BEWARE!!

There is a new "Gang Initiation"!!!!!

This new initiation of MURDER is brought about by Gang Members driving around at night with their car lights off. When 
you flash your car lights to signal them that their lights are out, the Gang members take it literally as "LIGHTS OUT," so they are to follow you to your destination and kill you!! That's their initiation.

Be aware and inform your family and friends.

Don't flash your car lights to anyone. ${ }^{\mathrm{T}}$

It is remarkable that with such brevity both spreads were very intense. There were several particularities that allowed this urban legend to cross the United States from coast to coast in a few weeks during I993 causing considerable alarm (Brunvand, 2000, pp. 95-I06. Donovan, 2004, p. 4). The transmission was not only oral, it also appeared in print, sometimes on headed paper, and was widely shared through fax machines (Brunvand, I995). New technologies speeded the process and may have given the message extra credibility. A fixed date also helped to fuel the spate. Some versions of the legend said that September 25 and 26 would be the initiation weekend for the Bloods, the allegedly involved gang, which was described in multiracial terms applying to different ethnic groups ("Asians, Latinos, blacks and whites") (Fine and Turner, 200I, p. I 86). This probably has to do with the brevity of the warning: the description of the threat is so sparse that it allows any social group to fit as the villain.

The same urban legend had an even more acute spread in Mexico twelve years later with remarkable similarities in the process of transmission (Soltero, 20I6b). It scattered intensively through email during October 2005 warning almost word by word (now through email and in Spanish) about the same gang, whose initiation rite would take place during the last weekend of the month $\left(29^{\text {th }}-30^{\text {th }}\right)$. A memo dated 2I October 2005 from the Director General of Interpol Mexico leaked to the media and had a very strong transmission from there. Contrary to the many apocryphal memos in headed paper that endorsed the transmission in the United States, this one was authentic, a detail that contributed substantially to the spread of the rumor. The height of the affair came on 27 October. The spokesman of the Mexican President declared in a press conference that they were aware of the presence in the country from members of this criminal gang that intended

I Typical flyer warning of the spread in the United States during 1993 (Fine and Turner, 200I: I84). 
to kill drivers and that the Republic's General Attorney's Office (the Procuraduría General de la República - in charge of all federal police forces) was acting upon it. Police from at least eight different states declared a maximum alert and started special operations and checkpoints to detect cars driving without lights. The Senate approved an urgent measure asking the President to reinforce police vigilance in highways close to the southern border of the country. The media reported all these events and accelerated the intensity of the spreading cycle. (Soltero, 2016b)

Not long after "Lights Out!" caused such turmoil in Mexico a different urban legend started to spread through the country's email networks. It featured a victim, usually female, in the parking lot of a shopping center looking for a public phone. A man with one leg and crutches approaches her and asks help to dial a number from a piece of paper. When she holds the paper, she starts feeling dizzy, runs for her car and manages to get to the hospital just before passing out. When she recovers, a doctor tells her how fortunate she was as lately there have been several cases like this, but with far worse endings - some leading to organ trafficking. In slightly varying versions the victim is not so lucky and dies because of the ordeal. In all accounts the victim is drugged with a substance from Colombia called burundanga or scopolamine. Burundanga is capable of subduing whoever smells or touches it, transforming the person into a zombie and erasing all memories of what happens during the trance.

Folklorism has developed two useful categories: motif and cognate version. Brunvand has referred to motif as: "a traditional narrative unit such as a character, an incident, and object, or any other remarkable detail that occurs repeatedly in myths, legends, and folktales" (Brunvand, 200I, p. 27I). In the case of "Lights Out!" a motif is the gang initiation rite; in "Burundanga", another one is the one-legged man who baits the victim. The fixed set of motifs that forms the recognizable core of any tale or narrative is the cognate version. Most folk material will have a fixed set of motifs and a mutable one.

The "Burundanga" urban legend has several particular characteristics: spatial, compositional and temporal. There were previous strands of this legend to this spread. During the I990s stories 
that treated burundanga seriously appeared in newspapers in the United States and the United Kingdom. In 1995 The Wall Street Journal published an article with the following subhead and opening line: "If you thought cocaine was bad news, wait until you hear about Burundanga. Burundanga is a kind of voodoo powder obtained from a Colombian local plant" (de Córdoba, I995). A 1999 article in The Guardian also refers to this period thus: "a mass panic of about five years ago that swept Colombia: the country was in the grip of a crime wave caused by the use of a plant drug known locally as burundanga" (Jay, I 999).

This situation and its media coverage left as a legacy the warnings in several Foreign Offices websites that, even if most aspects of the legend have been disproved, continue online. At the time of this writing, the Spanish Foreign Office reproduces verbatim fragments of the cognate version of the urban legend as a warning for its citizens heading towards this South American Country (Ministerio de Asuntos Exteriores y de Cooperación, no date). ${ }^{2}$ The British counterpart website warns that: "The British Embassy has received reports of criminals in Colombia using drugs to subdue their victims. This includes the use of scopolamine, which temporarily incapacitates unsuspecting victims. Drugs can be administered through food, drinks, cigarettes, aerosols and even paper flyers. Victims become disoriented quickly and are vulnerable to robbery, sexual assault, rape and other crimes. Avoid leaving food or drinks unattended and don't take anything from strangers" (Foreign Office, no date). Meanwhile the U. S. State Department more objectively warns that: "Disabling Drugs: Criminals may use drugs to temporarily incapacitate unsuspecting victims and then rob or assault them. Avoid leaving food or drinks unattended at a bar or restaurant, and use caution if a stranger offers you something to eat or drink" (U. S. Department State, no date).

\footnotetext{
${ }^{2}$ The Spanish website literally warns: "Existe una droga que se denomina escopolamina o popularmente 'burundanga', que mezclada con una bebida, un cigarrillo o incluso inhalada (por ejemplo de un papel que se muestra con la apariencia de preguntar por una dirección), hace perder la voluntad en forma absoluta, siendo utilizada para robos, secuestros, asaltos a domicilios. Debe pues rechazarse cualquier ofrecimiento de bebidas, cigarrillos, comida, etc. de desconocidos, así como evitar que se pueda poner cualquier papel, tela u otro objeto cerca de la nariz."
} 
Due to the dates of the transmission and the subsequent official warnings that include the exact wording it can be asserted that both the Spanish and British Foreign Offices warnings have been nurtured by the urban legend. The British websites mentions de use of paper flyers by criminals, and the Spanish one goes to even more detail by saying that only smelling the drug impregnated on a piece of paper, as with an address that is asked about for directions, produces a complete loose of will, which is extremely similar to the motif of the urban legend where the man with crutches gives the woman a piece of paper asking for help to dial a telephone number. That Foreign Offices from developed countries incorporate information from folk risk narratives is a good example of how rumors and urban legends may shape institutional action and public policy.

Contrary to "Lights Out!" the specific cognate version of "Burundanga" I refer to, with the man on crutches and the female victim drugged by only holding a piece of paper, circulated first in Spanish through South America, and then spread upwards through the continent. I have found coverage of its trail in newspapers from Chile, Argentina, Bolivia, Perú and Venezuela, ranging from 2003 to December 2005..$^{3}$ None of these are debunking articles or columns (unlike the media stories that appeared in the United States during the 1993 transmission of "Lights Out!"), but newspaper stories that reproduce as real the urban legend featuring the shopping center parking lot and the one-legged man. The collected emails from Mexico range from December 2005 to December 2007. This suggests that although the internet crosses international borders, national and linguistic networks still seem to largely modulate the flow of its contents.

The website Snopes.com, specialized in urban legends, dates the beginning of the United States spread in May 2008, when it started its circulation in English. It rapidly became very prolific. Although with several variations, the warning about criminals using burundanga-soaked business cards to incapacitate their victims is basically the same that circulated through Latin America.

3 The South American newspapers are: La cuarta 26 June 2003 and Con Tinta Negra 2003 from Chile; La Razón from Bolivia 22 July 2004; and El Universal 23 December 2005 from Venezuela. 
It still keeps some traces of this South-North transit, such as the unnamed victim being a neighbor of a "Jaime Rodríguez", a character with a Hispanic name (Snopes.com, 2008).

Following Knapp's classification, “Lights Out!" and "Burundanga" would clearly fit as bogy rumors that play upon the fears and anxieties of those sharing them, but they also have a distinct mark of wedge drivers that project such feelings as hostility towards deviant others. In the case of "Lights Out!" towards youth gangs, immigrants and even unknown drivers; with "Burundanga" towards foreign substances and people living on the street. The above concur with findings from other researchers about a widespread fear in large cities towards strangers that may attack randomly (Best and Horiuchi, I985, p. 492. Best, I999, p. xi. Donovan, 2004, p. I66). Therefore, any person that we do not personally know becomes a plausible threat. A belief that may have considerable implications for the social tissue of a community.

As mentioned, urban legends have two sets of motifs, the permanent ones that form the cognate version of legends and the mutable ones, which present enlightening mutations about how some social groups are perceived by others. In an example provided by Brunvand, “The Choking Doberman”, a woman arrives to her home and finds her dog gasping at the entrance. She takes it to the veterinary and returns home. When she arrives the phone rings. It is the veterinary who tells her to run out of her house without asking any questions. The police turn up and let her know that the dog had a couple of fingers stuck in its throat. They search the house and find the thief in a closet, bleeding from this wound. Several details differed among the versions that circulated through the United States: "Variations of this legend mention different breeds of dog, different hiding places of the intruder, and sometimes other numbers of fingers, often specified as 'black fingers' or 'Mexican fingers'” (Brunvand, 200I, p. 7I).

This last variation adapts the legend to local fears and relates to the topic of otherness in urban legends. Fine elaborates upon this point thus:

As the homogeneous cultures of industrialized nation-states mutate, becoming more multicultural, rumors that target recent immigrants (legal or illegal, temporary or permanent) frequently appear. 
[...] Rumors detail the arrival of dangerous spiders, insects, or snakes in clothing, rugs, foodstuffs, or plants, claiming that innocent consumers have suffered the consequences of exposure to these deadly products from exotic locations. On can immediately sense parallels between these dangerous animals and migrants, often hidden as well $(2007, \mathrm{pp} .3,4)$.

The above strongly relates to specific motifs that appear in both urban legends reviewed here. The violent gang and the burundanga substance have similar attributes. Like the animals and items described in the previous paragraph, or the foreign substance used to repair shoes Bourke mentions from the Bethnal Green panic, they are foreign, evil and unpredictable. This is very similar to what Fine states about how mistrust in products from abroad is a projection towards immigrants. For example, in "Burundanga" the prejudices towards Colombians are expressed through the powers of the substance and reactions to it, as it will become clearer in the following section.

\section{The Metaphorical Meaning}

How is it possible that in the XXI century, amid so many advances in science, technology and communications, we still resort to rumors and legends, which usually carry false information, to understand what is happening around us? In this sense, what is revealing about ongoing crime legends is that even if their referential content is dubious, the meaning they carry is "true", or goes beyond the notion of truthfulness as factuality. Urban legends frequently remain unassailable to debunking attempts: because they carry meaning. Donovan found that people believe and send urban legends by email because of the instrumental value they find in them as cautionary tales. It is not important if they actually happened or not, they are taken as useful warnings that let people understand the potential dangers of the world (Donovan 2004, p. I3 I). Some of the cultural subtexts these messages seem to carry are not expressed straightforwardly, but metaphorically: one of the ways in which narratives achieve meaning. I attempt to draw some insights from the metaphorical reading of these legends, their process of communication and political implications. In rumors and contemporary legends a clear displacement occurs: what they 
depict and warn about is rarely true, but they reflect real fears and anxieties of the community which may not find other ways of being verbalized or channeled. Allport and Postman indicated that the legends expressive functions are more important than their informative role (1947, p. 198). Their true meaning is not in what they describe, but in what they may symbolize and signify: their metaphorical content. Dundes also spoke about the importance of this figure of speech: "I favor relying upon folk metaphors. I assume that metaphors are meaningful, not accidental, and that there are consistent patterns of metaphor in every culture" (I980, p. $\mathrm{x}$ ). What will be now explored is precisely how metaphor in "Lights Out!" and "Burundanga" contributes to build meaning in those sharing the legends.

Metaphor is one of the most natural cognitive tools to fulfil effort after meaning: Lakoff and Johnson dedicated a volume to analyze why metaphor is so frequently present in everyday life, in language, thought and action (2003). They believe it is crucial for the way we understand the world, to the degree that: "[o]ur ordinary conceptual system, in terms of which we both think and act, is fundamentally metaphorical in nature" $(2003$, p. 6). Paul Ricoeur delved into Aristotle before starting to formulate his own work on metaphor: “'To metaphorize well', said Aristotle, 'implies an intuitive perception of the similarity in dissimilars'" (Ricoeur I978, p. 6). Lakoff and Johnson seem to agree with this principle, mentioning that: " $[t]$ he essence of metaphor is understanding and experiencing one kind of thing in terms of another" (2003, p. 5) Ricoeur, who is interested in studying narrative in action, believes that the natural abode of metaphor is the verb to be. He writes: "[t]he metaphorical 'is' at once signifies both 'is not' and 'is like" (I978, p. 7). To give an example, eyes are not stars, but the former have frequently been praised by comparing them with the latter.

While asking what metaphorical statements might say about reality, Ricoeur states that: "[ $\mathrm{t}]$ his question carries us across the threshold from the sense towards the reference of the discourse" (I978, p. 216). He gives a first definition of metaphor as: " $[t]$ he rhetorical process by which discourse unleashes the power that certain fictions have to redescribe reality" (I978, p. 6). In the case of contemporary legends metaphor may allow narrative to produce meaning through what could be called secular parabolic 
observations about reality: simple stories from which important truths (meaningful representations) about society and others may be deducted. This function would be fundamental for understanding, especially during effort after meaning when facing change.

In the case of the crime legends analyzed here, what could be its metaphorical meaning? "Lights Out!" is metaphorical from its very title. The name came from the implication during its transmission in the United States that drivers alerting others driving at night without lights could end with their own lights put out - meaning murdered. The metaphor comprises a first comparison between lights and life which recalls the well-known verses from Shakespeare, where Othello muses about taking his wife's life: "Yet she must die, else she'll betray more men. / Put out the light, and then put out the light" (I997, p. 2163).

On another level, Giddens' reading of Goffman provides a very relevant insight into the matter in the case of "Lights Out!". The former author uses the studies of the latter about behavior in social situations, such as civil inattention and hate stares (2009, pp. 8I-82). Civil inattention takes place when pedestrians who do not know each other cross on a sidewalk. They eye one another discreetly for a moment and then look away. Goffman refers to this operation as an act of courtesy in which: "the individual implies that he has no reason to suspect the intentions of the others present and no reason to fear the others, be hostile to them, or wish to avoid them" (I963, p. 84). It seems to work as a confirmation of a healthy social tissue.

Goffman's observations took place in the United States towards the late I950's, where in the south some Caucasians were known to give "hate stares" to African Americans, reproving their sharing of the same public space ( $1963, \mathrm{pp} .83-84$ ). Giddens puts forward as a complimentary and contrasting example the avoidance of eye contact in tough neighborhoods: "[a] lack of elementary trust in the possible intentions of others leads the individual to avoid catching their gaze, which might precipitate a potentially hostile engagement" (2009, pp. 8I-82). Both behaviors relate to the penetration of persons of a certain type to specific social settings, which relates to efforts of avoiding what Goffman calls "contamination by undesirables” or physical assault (I963, p. Io). 
Goffman's observations show the importance of visual interaction in social settings, and it is interesting how deeply it connects with conflict in the street. As representations in popular culture or personal experience show (one only needs to look it up in Google Images or try it in a bar), one of the most common phrases to engage conflict in several languages is: "What are you looking at?". Looking at someone in the wrong way could bring trouble or even be lethal. Similar to the example of metaphor that compares eyes with stars, lights can also denote metaphorically our sight. Goffman actually refers to the lowering of eyes that follows glancing briefly at strangers in civil inattention as: "a kind of dimming of lights" (1963, p. 84). In this context, the comparison also applies to the other forms of visual behavior mentioned above. Eye contact avoidance in tough neighborhoods would be equivalent to "turning your lights off" with the hope to pass unnoticed, and hate stares as putting the "headlights on high beam".

Giddens affirms that: "Civil inattention is the most basic type of facework commitment involved in encounters with strangers in circumstances of modernity" (2009, p. 82). It stands for the trust people who do not know each other may have in one another due to forming part of the same society, an expression of bodily language that means: "I can trust you and you can trust me." The metaphorical meaning of "Lights Out!" seems to deeply relate a perceived erosion of social fabric: it states that civil inattention, and other conventional ways of behavior in public that guarantee the peaceful coexistence of strangers, cannot be taken for granted any more.

Brunvand mentions about this legend that carrying out a socially caring act in the current environment can be misinterpreted as an aggression to drivers who are outsiders to those standards (2000, p. I05). These metaphorical associations would seem to confirm that "Lights Out!" speaks about the social tension felt in the environment, and about fears of outsiders unused to local conventions and dangerous for the local group. The people sharing the message assert that they cannot trust strangers because they may prove harmful even when the local community intends to do good.

Globalization has brought along constant and fast-paced change which can be a source of concern and anxiety. One of such 
changes has been an increased rate of immigration almost everywhere. The arrival of migrants is frequently a cause of tension among the local population. Fine and Ellis assert that "Whether the concern is terrorism, immigration, or international trade, Americans-along with citizens of other advanced nations-see threats from abroad. [...] Unwashed masses seem to threaten our clean lives." (2010, p. 2). These "unwashed masses" that the local population fears, sound very similar to Trump's bad hombres mentioned in the Introduction. After years of being president he did not change his views, as can be deducted from his questioning of why the country he rules should receive immigrants from "shithole countries" referring to El Salvador, Haiti and African states (Dawsey, 2018).

It is interesting to note that in "Lights Out!" there is no hint of the criminals' nationality, no description whatsoever, just the implication that they are young. Notwithstanding, during the transmission the criminal gang becomes identified with a particular nationality or ethnic group, which varies depending on the society or group passing the rumor. Brunvand followed the "Lights Out!" spread through the United States and collected all the news items in its wake. Among them was a story by AP which featured an author quoted in this chapter: "Fine voiced the opinion that 'gang in this particular rumor is a code word for poor, young black men'” (in Brunvand, 2000, p. I02). While in the United States the gang was usually interpreted to be formed by African American youths, when the same legend circulated in Mexico it was associated by the media and police authorities with La Mara Salvatrucha, the Central American gang with Salvadoran origins. Such projection was intense enough to motivate the Parliament into demanding the Mexican president to increase the surveillance of the southern border. In "Burundanga" the criminals' nationality is not spelled out, but as the substance is said to come from Colombia, they were implied to be Colombian as well.

The triggering Interpol memo declared that the alert had been received from Interpol Guatemala. One of the news stories in Mexico mentioned that the Interpol description of the Blood gang brought to mind the codes of the Mara Salvatrucha. In the same story the presidential spokesman is reported to have said that the gang members would use fire weapons (Arvizu Arrioja, 2005). 
The subhead of another story warned directly against a "group of Guatemalans" (Fernández and Herrera, 2005). Aguilar Padilla, the governor of the northern state of Sinaloa (over $2,500 \mathrm{~km}$ from the Mexican Southern border), confirmed that his state police forces would implement the actions of the national alert, watching bus and train stations, air terminals and ports, in order to proceed with a rigorous search of all Central American travelers (Cabrera Martínez, 2005). The text of the warning never touches upon the nationality of the gang or the weapons they might carry, as asserted in these political and journalistic claims. As it happened in the United States, the brevity of this warning allowed almost any deviant social group to fit as the villain.

The criminals in "Lights Out!" are gang members, bad hombres who belong to the unwashed masses. A cultural difference that can be ascertained from the comparison between the "Lights Out!" transits in the United States and Mexico is that what may be perceived as homogenous in one country, as happens with Latinos in the former, is identified as completely different in LatinAmerican countries. Fine and Ellis include as an example the opinion of a student in Hazelton, which showed the consensus felt by her whole family: "illegal Hispanic immigrants bring with them terrible violence [and] gang related crimes, and these two factors lead to the harm and death to unsuspecting innocent American citizens" (2010, p. I02). Similarly, one of the terms used by white residents of Hazelton, Pennsylvania, to name the incoming Latino population was "Mexicans", although it was mostly conformed by Dominicans (Fine and Ellis, 2010, p. 98). This same dread is precisely what Mexicans felt about illegal Central American immigrants during the 2005 transmission of the warning in their own country (Soltero, 202I pp. I4I-I42, I95-I96). The fact that Mexicans migrate to the United States and are the common denominator of the Hispanic unwashed masses feared by local populations there, does not prevent the Mexicans that stay home to fear their own Southern neighbors with whom they clearly did not feel an immediate kinship. It seems that every country has their own "unwashed masses" to be weary of.

Let us now look at "Burundanga". In this case its metaphorical sense may come out more clearly by putting together three 
seemingly unrelated motifs or points: dirt, innocent gifts as apples and the mythical halcyon years of communities. Regarding the first point, Douglas explored the meaning of dirt in different societies and historical moments through the opposing but complementary ideas of "purity and danger" (I992). Douglas asserts that in any society dirt is what is considered to be out of place. In order to comprehend the differences of what is regarded as clean and unclean and why, it is necessary to take into account the particular social and historical context. The assigned values of purity and danger frequently have symbolic social meaning: "as we examine pollution beliefs we find that the kind of contacts which are thought dangerous also carry a symbolic load. I believe that some pollutions are used as analogies for expressing a general view of the social order" (Douglas, I992, p. 3).

Douglas contribution about this symbolical understanding of purity and danger is very relevant here, because the crime narratives studied in this chapter serve as metaphorical warnings about the danger of evil polluting a community which sees itself as originally good. As Brunvand noted about "Lights Out!": "One persistent fear that both the general public and newspapers responded to was the idea of dangerous gang activity entering one's own community from some outside source" (2000, p. I05). Fine and Ellis declare that assertions linking the incoming groups with dirt and disorder are common in the collective imagination, and apply even if the ethnicity and origin of the out-group changes through time (Fine and Ellis, p. I0O). Again, outsiders of this kind are, clearly, part of the unwashed masses that arrive to a community self-perceived as "clean".

In the I970s and I980s Halloween rumors caused a profound panic in the United States, to the point of nearly cancelling the "Trick or Treat" tradition, due to stories of people tampering with the treats (Best and Horiuchi, I985, p. 490). One of the main motifs of this rumor was the idea that razor blades were introduced in apples and then given to children. When the emotions are drained from the tale its premise folds: it seems nearly impossible to hide a razor blade in an apple and leave the fruit unscathed. Even news media as Newsweek and The New York Times published articles warning about it. Although this panic has been 
studied by several scholars (Dégh and Vászonyi, I983. Best and Horiuchi, I985. Glassner, I999), so far, a folk motif profoundly related with Halloween has not been mentioned: how witches use apples for poisoning innocent victims, as happens for example in Snow White. Similarly, the idiomatic expression: "One bad apple spoils the whole bunch" seems very relevant here and the apple is also the forbidden fruit through which Paradise was lost. In all of these cases the apple is used as a metaphor of how danger or evil may contaminate an innocent party.

The substance used with criminal purposes in the legend of "Burundanga" could be seen as an equivalent to the apple in the fairy tale of Snow White. It is given in a deceivingly innocent presentation, similar to a piece of paper with a telephone number or a sample of perfume, but a horrible outcome awaits whoever bites into the plot. Just like Snow White, the victims lose their will and consciousness. The metaphoric function of the substance also links with the emotions provoked by the context of modernity and globalization referred to in here. Events and outcomes stop being in the hands of individuals who fall to the substance, as it may happen at times in the current social environment. The lack of control felt in the social context is made concrete in a foreign malignant substance.

\section{Discussion: From Narrative to Action}

But was the past really a pure and golden age? The historian Geoffrey Pearson set out to locate the idealized and harmonic past in Britain, but found that it remains elusive in actual historical time (Pearson, I983). He made a comparative study that confronts this vision of the past with the notion in the United Kingdom according to which: "after centuries of domestic peace, the streets of Britain have been suddenly plunged into an unnatural state of disorder" (I983, p. ix). Pearson developed the expression of respectable fears to understand how the privileged groups of society hold responsible other groups for this sense of social decline - in other words how the center blames the periphery. The members of the groups held responsible were generally young males, sometimes immigrants, such as black people at the time Pearson's work was published, but previously Irish and frequently 
working-class adolescents. He contrasts historically this causal explanation against the nostalgic image of peace and order held by the center by going back during a century in periods of twenty years and comparing these notions with the actual state of affairs (pp. 9-II). In general, the perception of the past and its historical reality do not match. At each of these precise moments, separated from each other by two decades, the social perception voiced through politicians and the media is that the state of disorder is at its acme, unlike twenty years earlier (e.g. pp. I 2-I6). And through their institutionalized voices the center pins down the blame upon the aforementioned members of the periphery, such as immigrants and working-class youth.

What Pearson calls respectable fears resembles what Bauman underscores from Wacquant about deviant others: "Public display condenses attention on 'recidivists, obtrusive beggars, refugees on the move, immigrants to be expelled, prostitutes on sidewalks and other kinds of social rejects' who litter the streets of metropolises to the displeasure of the 'decent people" (in Bauman 2006, p. I45). Wacquant aimed to show how the policies recently adopted by governments that insisted on being tough on crime, served mostly to punish those cast out by neoliberal economic policy (2004). This is done not only judicially, but through the representations that such displays usually carry through their narratives. For example, in Trump's quotes at the beginning of this chapter he characterizes Mexicans in the United States as "bad hombres", rapists and drug dealers, criminalizing people that usually leave their country to seek better opportunities in another one. Such narrative paves the way and sets the agenda for a more severe immigration reform and border control. For Breton et al. social tissue is the social and normative infrastructure upon which society relies. Social fabric implies a covenant "that defines what individuals can expect from the society and what the society can expect from them [...] what individuals can count on when dealing with each other and with institutions and their agents" (2004, p. 4). The authors specify that one of the things that individuals expect from other members of society is not being taken advantage of, just as they are expected to feel an obligation in helping others (Breton et al., 2004, p. 49). This is the precise thread of the social fabric that the crime legends in this chapter grind down 
narratively: the other stops being seen as a fellow human being to become a potential predator. These legends corrode trust among citizens who do not know each other personally and manifest the lack of confidence in institutions.

Bauman believes that the crisis of trust deeply affects human relations, which stop being realms of confidence and comfort to become sources of anxiety (2006, p. 69). Furthermore, as social bonds are the cornerstone of solidary action their dissipation seriously affects the latter (Bauman, 2006, p. 2I). These narratives, their process of transmission, and the degree to which lost guardianship is felt question the larger Us of society and leaves precaution and protection to the narrower Us embodied by those who share the narratives.

Shariatmadari summarized some of the expressions used recently in the United Kingdom to refer to migrants: a swarm of people, marauding, a tidal wave, a flood or stream, which are equivalent to: migrants are insects and hence animals; an invading army; migration is equivalent to an inundation to the point of natural disaster (2016). All dehumanizing metaphors that fit with the populist xenophobic rhetoric so present in the political arenas of several countries. The most worrying part is that these expressions come from politicians, like the prime minister and the chancellor, and the media, even official broadcasters with a serious reputation like the BBC (Shariatmadari, 2016).

Fine and Ellis concur that rumors about migrants tend to suggest that they are evil and intend to import danger, which is exactly what Donald Trump has been suggesting about migrants from Mexico, and elsewhere. A metaphorical construction present here compares immigrants to a virus that feeds on the strength of a community or nation; they are taken for "potential sources of cultural infection" (Fine and Ellis, 2010, p. 78). This impression of a sick body subject to disease is a cultural image that has been used since long ago as symbolical currency in American politics The authors extend this metaphor contained in the rumors to the reaction that newcomers arouse in older residents "metaphorically akin to the physical body's immune reaction" (Fine and Ellis, 20IO, p. 75). Such relations can be found in Trump's rhetoric along with that of white supremacists. 
The real danger that comes from these narratives is that they might enact such worldviews. These questionable understandings, that heavily rely on metaphor, may have a considerable part in the political action of shaping policies. Ricoeur believed that the importance of metaphor is that it both represents and reconstitutes reality (I990, p. ix). The following declaration from Lakoff and Johnson concurs and fits almost chillingly in this context regarding the potential impact of this figure of speech: "Metaphors may create realities for us, especially social realities. A metaphor may thus be a guide for future action. Such actions will, of course, fit the metaphor. This will, in turn, reinforce the power of the metaphor to make experience coherent. In this sense metaphors can be self-fulfilling prophecies”. (2003, pp. I 56-I 57). The metaphors contained in the two urban legends analyzed for this chapter and the expressions used in Donald Trump's discourse clearly belong here, making migration, a process already difficult for most that go through it, even more precarious.

\section{Conclusion}

In this chapter urban legends about crime have been defined as short and shocking narratives that pretend to be true, are widely believed and shared among social groups notwithstanding their background or socioeconomic level. These stories have been remarkably apt to cross whole continents and emphasize the prejudices some in-groups have about out-groups, sometimes affecting the social sphere by the way they influence our perception of reality. The crime legends "Lights Out!" and "Burundanga", that spread intensively digitally between different countries, were analyzed finding that in their transit they managed to convince even carriers like the media, the police and political institutions, showing that they can shape public policy even at an international level. Their metaphorical contents and implications were examined to better understand how they express cultural subtexts and convey meaning. The fact that the same messages are adopted by different groups in different countries allow to see that local deviant social groups may always fit as the villains of these narratives, blamed for the growing uncertainty perceived in the environment. 
These two urban legends form part of the negative narratives that cross borders regardless of boundaries and, paradoxically, promote the will to strengthen such boundaries in every possible way. They contribute to the rhetorical fuel that has been powering the resurgence of populism in different parts of the world. Narratives about bad hombres (and women) erode the social tissue in a way that migration does not, with political consequences that are beginning to be seen in the current threats to specific social groups and universal human rights.

\section{Acknowledgements}

This work was supported by a Newton Advanced Fellowship of the British Academy (grant NAFRi 80233 ) and the Program UNAM-DGAPA- PAPIIT (grant IN405420).

\section{References}

Abbott, H. P. (2002). The Cambridge Introduction to Narrative. Cambridge: Cambridge University Press).

Agren, D. (2017). “'Bad Hombres': Reports Claim Trump Spoke of Sending Troops to Mexico," The Guardian, 2 February [Online]. https://www.theguardian.com/us-news/20I 7/feb/o2/bad-hombres -reports-claim-trump-threatened-to-send-troops-to-mexico

Allport, G. and Postman. L. (I947). The Psychology of Rumor. New York: Henry Holt.

Arvizu Arrioja, J. (2005). "Confirma Presidencia amenaza de la Sangre," El Universal, 28 October [Online]. Mexico. Available at: http://www.eluniversal.com.mx/notas/3 I 2732.html. (Accessed: October 20I0).

Bauman, Z. (2006). Liquid Fear. Cambridge and Malden, MA: Polity Press.

Best, J. and Horiuchi G. T. (1985). “The Razor Blade in the Apple: The Social Construction of Urban Legends," Social Problems, 32(5), pp. 488-499. 
Best, J. and Hutchinson M. M. (I996). "The Gang Initiation Rite as a Motif in Contemporary Crime Discourse," Justice Quarterly, I $3(3), \mathrm{pp} \cdot 383-403$

Best, J. (I999). Random Violence. How We Talk about New Crime and New Victims. Berkeley and Los Angeles: University of California Press.

Bourke, J. (2005). Fear: A Cultural History. London: Virago.

Breton, R. et al. (2004). A Fragile Social Fabric? Fairness, Trust, and Commitment in Canada. Montreal: McGill-Queen's University Press.

Brunvand, J. H. (I98I). The Vanishing Hitchhiker. American Urban Legends and Their Meanings. New York: W. W. Norton.

— (I995). “'Lights out!'. A Faxlore Phenomenon,” Skeptical Inquirer, I9(2), pp. 32-37.

-(ed.) (1996). American Folklore: An Encyclopedia. New York: Garland.

- (2000). The Truth Never Stands in the Way of a Good Story. Urbana and Chicago: University of Illinois.

(200I). Encyclopedia of Urban Legends. London and New York: W. W. Norton.

Cabrera Martínez, J. (2005). "Instalan alerta por pandilleros del grupo Sangre," El Universal. 26 October [Online]. México. Available at: http://www.eluniversal.com.mx/notas/3 I 262 I.html. (Accessed October 20I4).

Dawsey, J. (2018). "Trump Derides Protections for Immigrants from'Shithole'Countries.”'The WashingtonPost. I 2January[Online]. Available at: https://www.washingtonpost.com/politics/trump -attacks-protections-for-immigrants-from-shithole-countries -in-oval-office-meeting/20 I 8/o I/I I/bfco72 5 c-f7 I I- I I 7-9 I af- 3 I ac 729add94_story.html?utm_term $=.488$ off I 2 ac2 7 (Accessed: January 2OI8).

Ábalos, C. and Babul, F. (2003). "La burundanga llegó para quedarse." Con Tinta Negra. Available at: http://www.periodismo 
.uchile.cl/contintanegra/2003/octubre/sociedad2.html. (Accessed: April 2007).

de Cordoba, J., (1995). "Drugged in Columbia: Street Thugs Dope Unwitting Victims,” Wall Street Journal, 3 July, p. A .

Dégh, L. and Vázsonyi, A. (I983). "Does the Word 'Dog' Bite? Ostensive Action: A Means of Legend Telling," Journal of Folklore Research. 20 pp. 5-34.

Delumeau, J. (I978). La Peur en Occident (XVIe-XVIIIIe siècles). Paris: Fayard.

Donovan, P. (2004). No Way of Knowing. Crime, Urban Legends and the Internet. New York and London: Routledge.

Douglas, M. (1992). Purity and Danger: An Analysis of the Concepts of Pollution and Taboo. London and New York: Routledge.

Dunbar, R. I. M. (1993). Grooming, Gossip and the Evolution of Language. London and Boston: Faber.

Dundes, A. (I980). Interpreting Folklore. Bloomington: Indiana University Press.

- (I99I). The Blood Libel Legend: A Casebook in Anti-Semitic Folklore. Madison: University of Wisconsin Press.

Ellis, B. (I983). "De Legendis Urbis: Modern Legends in Ancient Rome," Journal of American Folklore 96, pp. 200-208.

- (2003). Aliens, Ghosts and Cults, Legends we live. Jackson: The University Press of Mississippi.

Fainé Brath, V. (2003) "Ojo con la burundanga: Droga mata la voluntad," La cuarta, 26 June [Online]. Santiago. Available at: http:// www.lacuarta.cl/diario/2003/06/29/29.07.4a.CRO..BURUN DANGA.html (Accessed: April 2007).

Fernández E. and Herrera. O. (2005). “Alerta máxima en Edomex ante supuesta pandilla," El Universal. 27 October [Online]. Mexico. Available at: http://www.eluniversal.com.mx/ciudad/7 I $805 . h t m l$ (Accessed: October 20I4).

Fine, G. A. (1992). Manufacturing Tales: Sex and Money in Contemporary Legends. Knoxville: University of Tennessee Press. 
Fine, G. A. (2007). "Rumor Matters. An Introductory Essay," in Fine G. A., Campion-Vincent V. and Heath C. (eds.) Rumor Mills. New Brunswick and London: Aldine Transaction, pp. I-9.

Fine, G. A. and Turner, P. (200I). Whispers on the Color Line. Rumor and Race in America. Berkeley: University of California Press.

Fine, G. A. and Ellis, B. (2010). The Global Grapevine: Why Rumors of Terrorism, Immigration, and Trade Matter. Oxford and New York: Oxford University Press.

Foreign Office [Britain]. (no date). Foreign Travel Advice: Colombia. Available at: https://www.gov.uk/foreign-travel-advice/colombia /safety-and-security (Accessed: September 20I7).

Geertz, C. (2000). The Interpretation of Cultures. New York: Fontana Press.

Giddens, A. (2009). The Consequences of Modernity. Cambridge MA and Malden: Polity Press.

Glassner, B. (I999). The Culture of Fear. New York: Basic Books.

Goffman, E. (1963). Behavior in Public Places. Notes on the Social Organization of Gatherings. New York: The Free Press.

Heath, C. (2007). "Introduction [To Chapter II]," in Fine, G. A., Campion-Vincent, V. and Heath, C. (eds.) Rumor Mills. The Social Impact of Rumor and Legend. New Brunswick and London: Aldine Transaction, pp. $8 \mathrm{I}-86$.

Jay, M. (1999). "Dupes, not dopes," The Guardian, I 8 September. Available at: http://www.guardian.co.uk/books/ı 999/sep/I 8/books .guardianreview3 (Accessed: March 2010).

Knapp, R. H. (r944). “A Psychology of Rumor,” The Public Opinion Quarterly 8(I), pp. 22-37.

La Razón. (2004). "La 'burundanga' llegó a Bolivia y la Policía no se enteró,” 22 July [Online]. La Paz. Available at: http://www.bolivia .com/noticias/autonoticias/DetalleNoticia2 I 65 I.asp (Accessed: April 2007).

Lakoff, G. and Johnson M. (2003). Metaphors We Live by. Chicago: University of Chicago Press. 
Ministerio de Asuntos Exteriores y de Cooperación [Spanish Foreign Office]. (no date). Recomendaciones de viaje. República de Colombia. Available at: http://www.exteriores.gob.es/Portal/es /ServiciosAlCiudadano/SiViajasAlExtranjero/Paginas/Detalle Recomendacion.aspx? IdP=42 (Accessed: September 20I7).

Morin, E. (I970). Rumor in Orleans. London: Heinemann.

Neubauer, H.-J. (I999). The Rumour. A Cultural History. London and New York: Free Association Books.

Pearson, G. (1983). Hooligan. A History of Respectable Fears. London and Basingstoke: Macmillan.

Ricoeur, P. (1978). The Rule of Metaphor. Multi-Disciplinary Studies of the Creation of Meaning in Language. London: Routledge.

(I990 [1984]). Time and Narrative, Vol. I. Chicago and London: The University of Chicago Press.

Shakespeare, W. (I997). The Tragedy of Othello, the Moor of Venice in The Norton Shakespeare. New York and London: W. W. Norton, pp. 209I-2I74.

Shariatmadari, D. (2015). "Swarms, Floods and Marauders: The Toxic Metaphors of the Migration Debate," The Guardian. Io August [Online]. Available at: https://www.theguardian.com /commentisfree/20 I /aug/Io/migration-debate-metaphors -swarms-floods-marauders-migrants (Accessed September 20I6).

Shibutani, T. (1966). Improvised News. A Sociological Study of Rumor. Indianapolis and New York: Bobbs-Merrill.

Snopes.com. (2008). Burundanga/Scopolamine Warning. Published: I I May 2008. Updated: 27 November 20I7. Available at: https:// www.snopes.com/crime/warnings/burundanga.asp (Accessed: June 2008).

Soltero, G. (202I). Conspiracy Narratives South of the Border. Bad Hombres Do the Twist. London and New York: Routledge.

- (2016a). "Crime Urban Legends in Mexico: A Case Study of Authorless Narratives that Contribute to Implicit Cultural Policy," International Journal of Cultural Policy. 22(2), pp. I 8 I-I99.

(2016b). "The Mexican Transmission of 'Lights Out!'” Journal of Folklore Research, 53(3), pp. I I 5-I35. 
U. S. Department State. (no date). Colombia. Available at: https://travel.state.gov/content/passports/en/country/colombia .html. (Accessed: I9 September 2017).

Uzcategui, L. J. (2005) “ ¡Cuidado con la burundanga!” El Universal. 23 de diciembre [Online]. Caracas. Available at: http://www .eluniversal.com/2005/I 2/23/imp_pol_art_23 I $50 \mathrm{~A} . \mathrm{shtml}$ (Accessed: June 2008).

Wacquant, L. (2004). Punir les pauvres. Le nouveau gouvernement de l'insécurité sociale. Paris: Agone.

Washington Post. (2015). "Full Text: Donald Trump Announces a Presidential Bid.” June I6 [Online]. Available at: https://www .washingtonpost.com/news/post-politics/wp/20 I 5/06/I 6/full-text -donald-trump-announces-a-presidential-bid/?utm_term=.ff $97 \mathrm{~d}$ b6e42ea (Accessed: September 20I7).

Weisberg, J. (2000). "Bush, In His Own Words.” The Guardian, 4 November [Online]. Available at: https://www.theguardian.com /world/2000/nov/04/uselections2000.usa 5 (Accessed: June 2010). 